\title{
ANALISIS NILAI-NILAI KEPEMIMPINAN DI SMA ISLAM CIKAL HARAPAN 1 BUMI SERPONG DAMAI
}

\author{
Teguh Yuwono ${ }^{1)}$, Angga Rovita ${ }^{2)}$, Diana Riyana $\mathrm{H}^{3)}$ \\ dosen universitas pamulang, email : ${ }^{1)}$ teguh.yuwono9@yahoo.co.id ${ }^{2)} \underline{\text { dosen01788@unpam.ac.id }} \underline{\text { dosen01667@unpam.ac.id, }}$
}

ARTICLES

INFORMATION

ABSTRACT

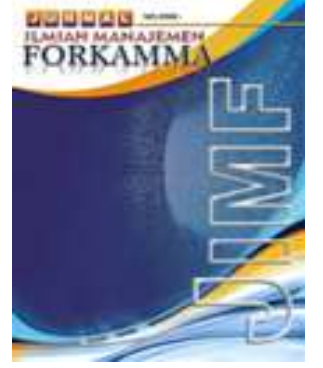

\section{JURNAL ILMIAH MANAJEMEN FORKAMMA}

Vol.2, No.1, November 2018

Halaman : $86-104$

(c) LPPM \& FORKAMMA

Prodi Magister Manajemen

UNVERSITAS PAMULANG

ISSN (online) : 2599-171X

ISSN (print) : :2598-9545

Keyword :

Value Leadership

JEL. classification :

C33, G20, G23, N65

\section{Contact Author : \\ PRODI \\ MAGISTER MANAJEMEN \& FORKAMMA UNPAM \\ JL.Surya Kencana No.1 Pamulang \\ Tangerang Selatan - Banten \\ Telp. (021) 7412566, Fax (021) 7412491 Email : \\ jurnalforkamma.unpam@gmail.com}

Tujuan penelitian ini adalah untuk mengetahui nilai-nilai kepemimpinan di SMA Islam Cikal Harapan 1 BSD dan Bagaimana nilai-nilai kepemimpinan diterapkan.

Metode penelitian yang digunakan adalah kualitatif, yaitu dengan cara melakukan wawancara dengan first hand information, Dari hasil wawancara dengan Kepala Sekolah SMA Islam Cikal Harapan 1 BSD ditemukan adanya nilai-nilai kepemimpinan yang mendasarkkan pada kebijakan yayasan yang menanungi sekolah tersebut, sehingga kepemimpinan berdasarkan struktur. Dari Fokus Grup Diskusi ditemukan adanya nilai-nilai kepemimpinan yang diharapkan dapat menumbuhkembangkan etos kerja para guru dan karyawan, sehingga diharapkan terbentuknya nilai-nilai kepemimpinan yang memberdayakan antara pimpinan dan bawahan (kepala sekolah dan jajaran guru serta siswa), maka diharapkan adanya sistem atau aturan yang menjadi dasar dalam menjalankan kepemimpinan. Adanya kesenjangan pemahaman nilai-nilai kepemimpinan dari hasil wawancara dan Fokus Grup Diskusi tersebut menimbulkan tantangan untuk dijawab, maka peneliti memberikan perspektif atau pandangan yang menyatukan dua sudut pandang ( pimpinan/kepala sekolah dan bawahan/guru dan siswa).

The purpose of the research to identify value of leadership and how to applied leadership value in Cikal Harapan 1 BSD Islamic Senior High School.

The research method used is qualitative, by conducting interviews with the principal as first hand information and Focus Group Discussion (FGD). Results of interviews with the Principal of Cikal Harapan 1 BSD Islamic Senior High School, there were found leadership values based on the school foundation's policy, so that leadership applied was based on structure.From the Focus Group Discussion found value of leadership applied which expect can develop work ethics of teachers and employees, then expect to formed of leadership values that empower between leaders and subordinates (principal,teachers and students), therefore a system or rule being expected as the basic of leadership implementation.There are gap of understanding leadership values from the interview results and Focus Group Discussion (FGD) raises the challenge to be answered, so the researcher provide a perspective or view that concatenate the two points of view (the head / principal and subordinates / teachers with students). And from the researcher's perspective, 


\section{A. Pendahuluan}

Pendidikan adalah syarat untuk mewujudkan kehidupan bangsa yang maju, modern dan sejahtera. Sebagaimana diketahui bahwa kemajuan suatu bangsa ditentukan oleh salah satu faktor yang sangat penting, yaitu pendidikan (education). Banyak negara yang tidak memiliki sumber daya alam yang melimpah namun dapat mewujudkan kemakmuran dan kesejahteraan rakyatnya. Hal tersebut dapat terjadi akibat dari pendidikan yang mereka miliki mempunyai kualitas yang baik, sehingga menghasilkan sumber daya manusia yang berkualitas. Agar pendidikan dapat berkualitas salah satu faktor penting yang harus dipenuhi adalah pada keberadaan pendidiknya (guru, kepala sekolah) yang bermutu, yang professional, sejahtera dan bermartabat.

Di era globalisasi saat ini, peningkatan mutu pendidikan kiranya menjadi masalah yang urgen. Peningkatan mutu pendidikan diperlukan pengelolaan organisasi pendidikan agar bergerak menuju satu arah. Pendidikan yang baik dan bermutu menjadi dasar pengembangan dan kemajuan selanjutnya. Oleh karena itu, pengelola pendidikan harus merespons berbagai kebijakan pemerintah dan keinginan masyarakat dalam kerangka perbaikan mutu dan kreatifitas, inovasi yang tinggi, dan strategi manajemen yang baik dalam konteks sistem (optimalisasi semua unsur manajemen sekolah baik proses input maupun output).

Dengan demikian, akan tercipta pendidikan yang lebih baik dan lebih maju untuk bersaing ditingkat regional. Nasional, dan global. Dunia pendidikan saat ini juga berkembang dengan sangat pesat dari waktu ke waktu. Pendidikan saat ini memang sudah sangat jauh berbeda dengan pendidikan dimasa lalu. Perkembangan teknologi, ilmu pnegetahuan sudah sangat pesat sehingga mempengaruhi dunia pendidikan saat ini. Lembaga pendidikan mulai banyak bermunculan sehingga tidak bisa dielakkan akan terjadi persaingan yang sangat ketat diantara lembaga-lembaga pendidikan itu.Lembaga pendidikan mempunyai tanggung jawab social yang sangat besar kepada bangsa ini bukan hanya sekedar untuk kepentingan bisnis semataLembaga pendidikan, merupakan salah satu sekolah yang mempunyai peranan sangat besar dalam mencerdaskan kehidupan bangsa. Lembaga pendidikan dikatakan bermutu dan memiliki peran aktif dalam mencerdaskan kehidupan bangsa, salah satu indikasinya adalah jika terdapat pemimpin dan tenaga pendidik yang bertanggungjawab, profesional di bidangnya, dan memiliki nilai moral yang tinggi.

Pernyataan pemerintah yang tercantum dalam Undang-Undang Sisdiknas No. 20 Tahun 2003 menyatakan bahwa fungsi dan tujuan pendidikan nasional yaitu: "Pendidikan nasional berfungsi mengembangkan kemampuan dan membentuk watak serta peradaban bangsa yang bermartabat dalam rangka mencerdaskan kehidupan bangsa, bertujuan berkembangnya potensi peserta didik agar menjadi manusia yang beriman dan bertaqwa kepada Tuhan YME, berakhlak mulia, sehat, berilmu, cakap, kreatif, mandiri, dan menjadi warga negara demokratis serta bertanggung jawab".

Sebagai pemimpin di lembaga pendidikan, kepala sekolah merupakan salah satu faktor penentu yang mempengaruhi partisipasi bawahan untuk melakukan apa yang menjadi tanggung jawabnya dengan perasaan puas dan dapat bekerja sesuai dengan konteknya, yaitu mampu memberikan visi, menciptakan gambaran besar, menetapkan tujuan yang jelas dan disetujui bersama, memonitor dan menganalisis prestasi, serta mampu mengembangkan prestasi para pengikutnya, yaitu dengan memberikan pengarahan dan panduan, melatih dan membimbing serta memberikan umpan balik. Oleh karena itu kepala sekolah harus memiliki pengetahuan yang luas, kemampuan manajemen dan keterampilan kepemimpinan. Keterampilan kepemimpinan bertujuan agar kepala sekolah dapat mengambil keputusan secara cepat, dan mampu mengendalikan, mempengaruhi dan mendorong bawahannya dalam melaksanakan tugas dengan jujur, tanggungjawab, efektif dan efisien. Keberhasilan sekolah sangat ditentukan oleh kemampuan kepala sekolah mengelola tenaga pendidik, meningkatkan kinerja guru, 
bertanggung jawab atas penyelenggaraan kegiatan pendidikan, administrasi sekolah, pembinaan tenaga kependidikan lainya, pendayagunaan, serta pemeliharaan sarana dan prasarana.

Di dalam organisasi, lembaga, maupun di lembaga pendidikan, "pimpinan" merupakan motor penggerak dan penentu arah kebijakan organisasi. Dalam sekolah / madrasah, pemimpin akan menentukan bagaimana tujuan-tujuan pendidikan dapat direalisasikan sehingga kepala sekolah dituntut senantiasa meningkatkan efektivitas kinerja dan memuaskan hasil kinerja lembaga. Kepemimpinan kepala sekolah sedikit banyak dapat mempengaruhi pendidikan di lingkungan sekolah. Sekolah juga membutuhkan figur pemimpin yang siap bekerja keras untuk dapat memajukan sekolah untuk meningkatkan mutu pendidikan di lingkungan sekolah yang dipimpinnya.

Kepala sekolah sebagai pemimpin lembaga pendidikan berfungsi sebagai penanggung jawab semua kegiatan di sekolah. Hal ini tercantum dalam Permendiknas No. 13 Tahun 2007 tentang Standar Kepala Sekolah, bahwa kemajuan suatu sekolah sangat ditentukan oleh kinerja kepemimpinan kepala sekolah. Dalam perspektif kebijakan pendidikan nasional (Depdiknas, 2006) terdapat tujuh peran utama kepala sekolah, yaitu sebagai 1) educator (pendidik, 2) manajer, 3) administrator, 4) supervisor/penyelia, 5) leader/pemimpin, 6) pencipta iklim kerja, dan 7) wirausahawan. Selain itu kepala sekolah juga harus memiliki kompetensi yakni: kompetensi kepribadian, kompetensi manajerial, kompetensi kewirausahaan, kompetensi supervisi, dan kompetensi sosial. Hal ini tercantum juga dalam Peraturan Pemerintah sebelumnya No. 28 tahun 2010, pasal 12 tentang tugas kepala sekolah menyatakan bahwa: "Kepala sekolah bertanggung jawab atas penyelenggaraan kegiatan pendidikan sekolah, pembinaan tenaga pendidikan dan pendayagunaan serta pemeliharaan sarana-prasarana". Kepala sekolah adalah seorang guru yang seharusnya mempunyai kemampuan untuk memimpin segala sumber daya yang ada pada sekolah sehingga dapat didayagunakan secara maksimal untuk mencapai tujuan bersama. Kepemimpinan kepala sekolah sebagai suatu kemampuan dan kesiapan kepala sekolah untuk dapat mempengaruhi, menggerakkan, dan membina para pendidik dan tenaga kependidikan yang lain sehingga mereka mau melakukan tugas-tugas pendidikan secara efektif dan efisien dalam rangka pencapaian tujuan pendidikan.

$\mathrm{Di}$ dalam organisasi, lembaga, maupun di lembaga pendidikan, "pimpinan" merupakan motor penggerak dan penentu arah kebijakan organisasi. Dalam sekolah / madrasah, pemimpin akan menentukan bagaimana tujuan-tujuan pendidikan dapat direalisasikan sehingga kepala sekolah dituntut senantiasa meningkatkan efektivitas kinerja dan memuaskan hasil kinerja lembaga. Kepemimpinan kepala sekolah sedikit banyak dapat mempengaruhi pendidikan di lingkungan sekolah

SMA Islam Cikal Harapan 1 BSD didirikan pada tanggal 01 Mei 2005 beralamat di Jl.Kencana Loka Blok B09 N0.1 BSD Tangerang Selatan. Sekolah Ini dikelola Oleh Yayasan Permatasari. Berdasarkan pengalaman, hasil pengamatan dan wawancara singkat terhadap kepala sekolah, pegawai dan guru pada presurvey di SMA Islam Cikal Harapan 1 BSD, keberhasilan kepala sekolah dalam mengantarkan kemajuan sekolah antara lain adanya pencapaian prestasi dalam akreditasi, yaitu mendapat akreditasi A.Di sisi lain, Kepemimpinan kepala sekolah SMA Islam Cikal Harapan juga menunjukkan fenomena yang kurang mengembirakan, hal dapat dibuktikan antara lain dari penerimaan siswa dari tahun ketahun yang cenderung menurun.

Tabel 1: Data Penerimaan Siswa ( sumber Data Sekolah )

\begin{tabular}{|l|l|}
\hline Tahun Ajaran & Jumlah Penerimaan Siswa \\
\hline $2015 / 2016$ & 158 \\
\hline $2016 / 2017$ & 126 \\
\hline $2017 / 2018$ & 106 \\
\hline $2018 / 2019$ & 95 \\
\hline
\end{tabular}

Sumber: Data sekolah per Juli 2018 
Dari data tersebut di atas menunjukkan adanya penurunan penerimaan jumlah siswa yang cukup signifikan. Hal ini tentu menjadi catatan tersendiri bagi sekolah dan perlu adanya evaluasi yang komprehensif. Hal lain yang tergali dari penelitian ini adalah bahwa Kepala Sekolah dalam proses pengambil keputusan kurang cepat, indikasinya adalah masalah yang seharusnya dapat diselesaikan dengan cepat, namun terlalu berlarut-larut sehingga tidak ada progres yang membanggakan. Hal ini tentu berakibat rendahnya kinerja guru dalam menjalankan program-program sekolah, kurang tertibnya dalam hal administrasi sekolah, sehingga urusan administrasi sering terlambat, misalnya pembuatan RPP dan administrasi guru dan sebagainya.

Kepala sekolah sebagai kontrol guru dan karyawan, harus memiliki kemampuan pengawasan yang baik, tetapi kenyataannya kontrol antara kepala sekolah dan beberapa guru kurang. Hal ini terindikasi adanya beberapa guru yang mengajar meninggalkan kelas. Hal ini mengakibatkan semangat kerja guru menjadi kurang. Kepala sekolah sebagai pimpinan institusi harus melakukan pengawasan, agar potensi sumberdaya manusia dari para guru dapat diberdayakan secara maksimal untuk mencapai kemajuan bersama. Berdasarkan sharing beberapa guru dan karyawan, kepala sekolah harus segera bergiat melakukan banyak pemberdayaan, dengan melakukan komunikasi yang kondusif terhadap semua lapisan yang dipimpinnya, baik terhadap guru senior maupun yang baru, sehingga organisasi sekolah lebih solid.

Dari latar belakang tersebut peneliti tertarik untuk menggali nilai-nilai kepemimpinan dan bagaimana implementasinya di sekolah ini, yang pada gilirannya hasil penelitian ini dapat memberi sumbangsih pemikiran dan masukan. Maka peneliti memilih judul yang berkaitan dengan hal tersebut di atas, yaitu "Analisis Nilai-nilai Kepemimpinan Di SMA Islam Cikal Harapan 1 BSD".

\section{B. Fokus Masalah}

Mengingat luasnya jangkaun penelitian, maka penelitian ini akan dibatasi pembahasannya pada nilai-nilai kepemimpinan yang digali secara mendalam serta bagaimana penerapannya pada SMA Islam Cikal Harapan 1 BSD dalam menyelenggarakan majunya sekolah.

\section{Tujuan Penelitian}

Berdasakan Fokus masalah di atas, maka tujuan dari penelitian ini adalah sebagai berikut :

1. Mengindentifikasi nilai-nilai kepemimpinan yang diterapkan oleh pemimpin SMA Islam Cikal Harapan 1 BSD

2. Menganalisa apakah nilai-nilai kepemimpinan yang diterapkan dapat diterima dan diimplementasikan dengan baik oleh pegawai yang dipimpinnya sehingga menghasilkan sinergi yang baik antara pemimpin dan pegawai pada SMA Islam Cikal Harapan 1 BSD.

\section{Manfaat Penelitian}

Dari hasil penelitian ini diharapkan dapat memberikan manfaat bagi beberapa pihak antara lain :

Bagi Pihak Sekolah :

1. Memberikan masukan apakah nilai-nilai kepemimpinan saat ini telah diterima dan dipahami dengan baik oleh pegawai SMA Islam Cikal Harapan 1 BSD sehingga tercapai sinergi yang baik antara pemimpin dengan pegawai yang dipimpinnya. 
2. Memberikan gambaran umum bagi pimpinan kepala sekolah mengenai nilai-nilai kepemimpinan yang perlu dikembangkan supaya tercapai kinerja dan produktivitas yang baik dalam memberikan pelayanan kepada guru, karyawan dan konsumen

Bagi Institusi Pendidikan :

Diharapkan penelitian ini dapat menjadi referensi dalam pengkajian nilai-nilai kepemimpinan.

\section{E. Landasan Teori}

Dalam kajian teori ini, penulis buat skema untuk memudahkan alur tulisan agar tersusun secara sistematis dan terstruktur dengan baik, yaitu sebagai berikut :

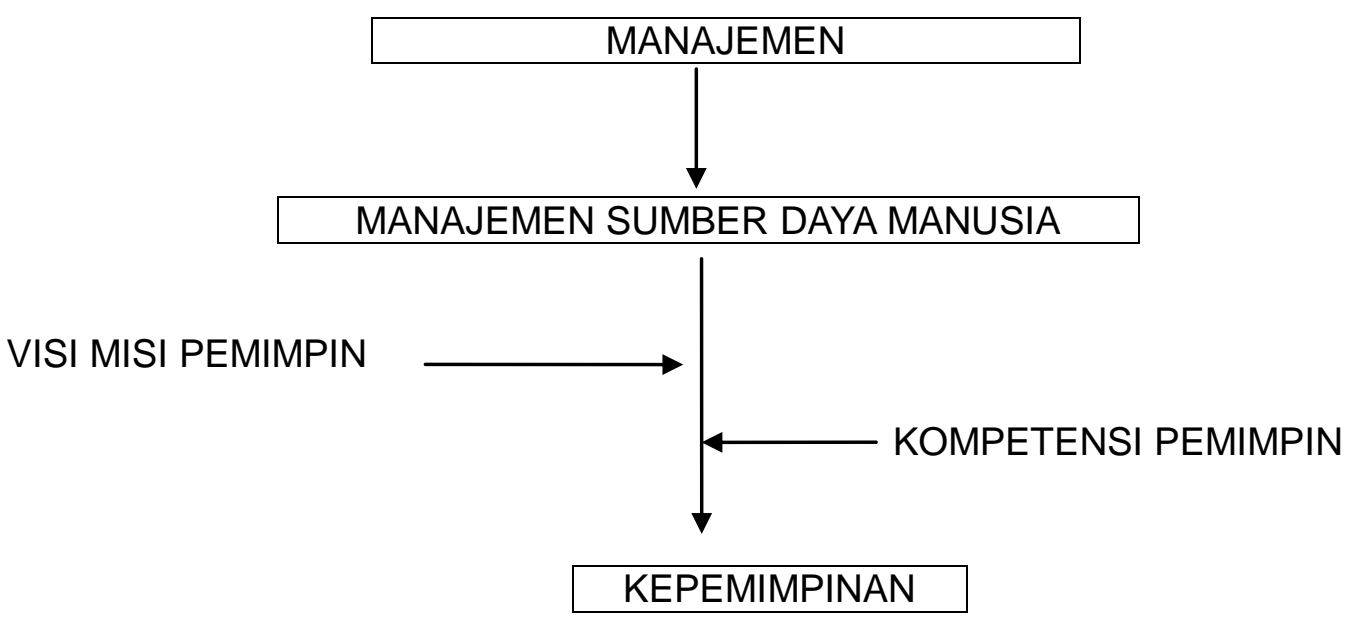

Gambar 2. Landasan Teori

Tinjauan pustaka dimulai dari landasan Teori Umum ( Grand Theory), berupa IImu manajemen ( Management) yang memiliki keterkaitan dengan Teori Antara ( Middle Range Theory) yang berunsurkan salah satunya adalah Manajemen Sumberdaya Manusia ( Human Resources Management). Middle Range Theory tersebut merupakan induk keilmuan dari teori aplikasi (Applied Theory) yaitu Kepemimpinan (Leadership) yang dijabarkan dari berbagai sudut pandang, visi misi serta kompetensinya.. Hal-hal tersebut menjadi landasan teoritik untuk menganalisa kepemimpinan di SMA ISLAM CIKAL HARAPAN 1 BSD yang semua itu bermuara pada implementasinya.

\section{Manajamen}

"Management is the process of planning, organizing, leading and controlling the efforts of organization members and using all other organizational resources to active stated organizational goals". Manajemen adalah proses perencanaan, pengorganisasian dan penggunaan sumberdaya-sumberdaya organisasi lainnya agar mencapai tujuan organisasi yang telah di tetapkan. ( James F. Stoner, dalam Umi Rusilowati : 2013) Mendasarkan pada pemahaman ( definisi) tersebut di atas mengenai manajemen sebagai grand theory, maka perlu dikemukakan beberapa aspek di bawah ini sebagai Middle Arrange Theory dan Aplikasinya, yaitu manajemen sumber daya manusia.

Manajemen menurut Koontz dan Cyril yang dikutip oleh Hasibuan (2009:3) mengemukakan sebagai berikut :

Manajemen adalah usaha mencapai suatu tujuan tertentu melalui kegiatan orang lain. Dengan demikian manajer mengadakan koordinasi atas sejumlah aktivitas orang lain 
yang meliputi perencanaan, pengorganisasian, penempatan, pengarahan dan pengendalian.

Definisi-definisi manajemen menurut para ahli di atas bermacam-macam pendapat, namun jika kita simak dari definisi-definisi di atas dapat disimpulkan, sebagai berikut :a) Manajemen mempunyai tujuan yang ingin dicapai,b)Manajemen merupakan perpaduan antara ilmu dan seni, c) Manajemen merupakan proses yang sistematis, terkoordinasi, koperatif dan terintegrasi dalam memanfaatkan unsur-unsurnya $(6 \mathrm{M}), 3)$ Manajemen baru dapat diterapakan jika ada dua orang atau lebih melakukan kerja sama dalam suatu oraganisasi. 4) Manajemen harus didasarkan pada pembagian kerja, tugas dan tanggungjawab.5) Manajemen terdiri dari beberapa fungsi.6) Manajemen hanya merupakan alat untuk mencapai tujuan.

Sebuah organisasi tanpa adanya manajemen dalam menjalankan kegiatan dapat menimbulkan ketidakaturan. Maka dari itu manajemen dikatakan penting dalam menjalankan kegiatan organisasi, pada dasarnya :a) Pekerjaan itu berat dan sulit untuk dikerjakan sendiri, sehingga diperlukan pembagian kerja, tugas dan tanggungjawab dalam penyelesaiannya, b) Organisasi akan dapat berhasil baik, jika manajemen diterapkan dengan baik,c) Manajemen yang baik akan meningkatkan daya guna dan hasil hasil guna semua potensi yang dimiliki, d) Manajemen yang baik akan mengurangi pemborosan-pemborosan, e) Manajamen menetapkan tujuan dan usaha untuk mewujudkan dengan memanfaatkan $6 \mathrm{M}$ dalam proses manajemen tersebut,f) Manajemen perlu untuk kemajuan dan pertumbuhan, g) Manajemen mengakibatkan pencapaian tujuan secara teratur,h) Manajemen merupakan pedoman pikiran dan tindakan,i) Manajemen selalu dibutuhkan dalam setiap kerja sama sekelompok orang.

\section{Manajemen Sumber Daya Manusia}

Manajemen adalah fungsi yang berhubungan dengan upaya mewujudkan hasil tertentu kegiatan orang lain. Hal ini berarti bahwa sumber daya manusia mempunyai peran penting dan dominan dalam manajemen.Manajemen sumber daya manusia pada hakekatnya adalah penerapan manajemen, khususnya untuk sumber daya manusia.

Banyak sekali pendapat yang dikemukakan oleh para ahli mengenai pengertian manajemen sumber daya manusia, seperti yang disampaikan oleh Henry Simamora ( 2004 : 3) yang mengatakan : "Manajemen sumber daya manusia adalah pendayagunaan, pengembangan, penilaian, pemberian, balas jasa dan pengelolaan individu anggota organisasi atau kelompok karyawan.

Pengertian senada dikemukakan oleh French yang dikutif oleh Sedarmayanti (2009:5) dalam buku "Sumber Daya Manusia dan Produktivitas Kerja" adalah sebagai berikut : "Manajemen Sumber daya manusia adalah penarikan, seleksi, pengembangan, penggunaan, dan pemeliharaan sumber daya manusia oleh organisasi".

Manajemen Sumber Daya Manusia juga menyangkut desain dan implementasi sistem perencanaan, penyusuanan karyawan, pengembangan karyawan, pengelolaan karir, evaluasi kinerja, kompensasi kayawan dan hubungan ketenagakerjaan yang baik".

Manajemen sumber daya manusia pada hakekatnya adalah penerapan manajemen, khususnya untuk sumber daya manusia. Pengertian manajemen sumber daya manusia yang dikemukakan oleh Edwin dan dikutip oleh Sedarmayanti (2009:5), sebagai berikut :Manajemen sumber daya manusia adalah perencanaan, pengorganisasian, pengarahan, dan pengawasan kegiatan-kegiatan, pengadaan, pengembangan, pemberian kompensasi, pengintegrasian, pemeliharaan, dan pelepasan sumber daya manusia agar tercapai berbagai tujuan individu, organisasi, dan masyarakat.

Manajemen sumber daya manusia mempunyai kekhususan dibandingkan dengan manajemen secara umum atau manajemen sumber daya lain, karena yang dikelola adalah manusia maka keberhasilan atau kegagalan manajemen sumber daya manusia akan mempunyai dampak yang sangat luas. Manajemen sumber daya manusia merupakan suatu pengakuan terhadap pentingnya sumber daya manusia atau tenaga 
kerja dalam organisasi, dan pemanfaatannya dalam berbagai fungsi serta kegiatan untuk mencapai tujuan organisasi.Pendapat lain mengenai pengertian manajemen sumber daya manusia menurut Mangkunegara (2011:2), bahwa manajemen sumber daya manusia adalah sebagai berikut : Manajemen sumber daya manusia merupakan suatu perencanaan, pengorganisasian, pengkoordinasian, pelaksanaan, dan pengawasan terhadap pengadaan, pengembangan, pemberian balas jasa, pengintegrasian, pemeliharaan, dan pemisahan tenaga kerja dalam rangka mencapai tujuan organisasi.

Manajemen sumber daya manusia mempunyai kekhususan dibandingkan dengan manajemen secara umum atau manajemen sumber daya lain, karena yang dikelola adalah manusia maka keberhasilan atau kegagalan manajemen sumber daya manusia akan mempunyai dampak yang sangat luas. Manajemen sumber daya manusia merupakan suatu pengakuan terhadap pentingnya sumber daya manusia atau tenaga kerja dalam organisasi, dan pemanfaatannya dalam berbagai fungsi serta kegiatan untuk mencapai tujuan organisasi.

\section{Kepemimpinan}

Salah satu definisi tentang kepemimpinan yang sangat umum dan banyak menjadi acuan, yaitu kemampuan mempengaruhi aktivitas orang lain baik individu maupun kelompok ke arah pencapaian tujuan. (Pandji, 2000). Mendasarkan pada definisi tersebut, maka setidaknya ada 3 implikasi penting, yaitu :

a. Kepemimpinan yang menyangkut orang lain

b. Kepemimpinan yang menyangkut kekuasaan

c. Kepemimpinan yang menyangkut soal pengaruh

d. Seorang pemimpin juga dituntut agar mampu memberdayakan orang-orang yang dipimpinnya. Inilah sesungguhnya visi misi pemimpin, yaitu "people development".

Stephen P Robbins (2009:419) "leadership as the ability to influence a group toward the achievement of a vision or set of goals. (Kepemimpinan sebagai kemampuan untuK mempengaruhi suatu kelompok terhadap pencapaian visi atau mencapai tujuan).Lebih lanjut Anindya ( 2015 : 15) menguraikan tentang ciri-ciri pemimpin yang baik, yaitu :

a. Dapat membuat orang lain menjadi lebih baik

b. Memberdayakan orang dengan baik

c. Memiliki kecerdasan emosional

d. Selalu menggunakan logika

e. Tidak berhenti belajar

f. Lebih banyak mendengarkan daripada berbicara

g. Selalu fokus pada solusi bukan masalah

h. Percaya diri dan tanggungjawab

i. Berkomunikasi secara efektif

j. Penuh dengan kasih sayang

k. Berani mengakui kesalahan dan berani minta maaf

I. Tidak takut mengambil keputusan besar

Menurut Gatot Iswantoro (2013), lain lagi, Pemimpin adalah seseorang yang karena kedudukannya aytau jabatannya, kewibawaannya memegang kendali atas suatu kelompok, unit, organisasi kemudian merangkaikan atau menetapkan dan menjalankan suatu kegiatan, kebijakan, aktivitas, tujuan dari kelompok/unit/organisasi tersebut dengan kinerja yang baik dan diharapkan dapat mencapai hasil yang positif. Searah dengan pengertian kepemimpinan sebagai kemampuan mempengaruhi dinyatakan pula oleh Edwar (2009:460), bahwa kepemimpinan; "the ability to influence the activities of other to through the process of communication, toward the attainment of a goal". (kepemimpinan adalah kemampuan untuk mempengaruhi orang lain melalui proses komunikasi ke arah pencapaian tujuan-tujuan tertentu).

Ivancevich(2008:413) kepemimpinan "as the process of influencing other to facilitate the attainment of organizationally relevant goals". Ivancevich mengatakan bahwa 
kepemimpinan merupakan perilaku seseorang dalam mempengaruhi orang lain untuk mencapai tujuan yang akan dicapai. Menurut colquit (2009:441) sebagai berikut: Leadership as the use of power and influence to direct the activities of followers toward goal achievement.That direction can affect followers interpretation of events, the organization of their work activities, their commitment to key goals, their relationships with other follower, and their acces to cooperation and support form other work unit.Dari pendapat Colquitt menjelaskan bahwa ada dua kata dalam kepemimpinan yaitu kekuasaan dan pengaruh. Kekuasaan dan pengaruh digunakan untuk mengarahkan pengikutnya menuju karget yang ingin dicapai. Pemimpin dapat mempengaruhi pengikutnya dalam kegiatan organisasi dengan target yang ingin dicapai dan pula mengarahkan bagaimana dapat bekerja sama dan mendukung dari unit lainnya, ada tiga implikasi yang penting dari kepemimpinan, yaitu: 1) Kepemimpinan harus melibatkan orang lain atau bawahan, 2) kepemimpinan melibatkan distribusi yang tidak merata dari kekuadaan diantara pemimpinan dan anggota kelompok, dan 3) pemimpinan dapat mengarahkan dan mempegaruhi orang lain. Searah dengan pengertian kepemimpinan sebagai kemampuan mempengaruhi dinyatakan pula oleh Michael Drafke bahwa kepemimpinan: "the ability to influence the activities of other to through the process of communication, toward the attainment of a goal".

Steven L. MCShane (210:360) mengatakan "Leadership is about influencing, motivating, and enabling others to contribute that the effectivenes and success of the organizations of which they are members". (Kepemimpinan adalah mempengaruhi, memotivasi, dan memungkinkan orang lain untuk berkontribusi bahwa efektivitas dan keberhasilan organisasi mereka dalam anggota). Searah dengan pengertian kepemimpinan sebagai kemampuan mempengaruhi dinyatakan pula oleh Edwar (2009:460), bahwa kepemimpinan; "the ability to influence the activities of other to through the process of communication, toward the attainment of a goal". (kepemimpinan adalah kemampuan untuk mempengaruhi orang lain melalui proses komunikasi ke arah pencapaian tujuan-tujuan tertentu).

Karakteristik seorang pemimpin didasarkan kepada prinsip-prinsip (Stephen R. Coney) sebagai berikut:1. Seorang yang belajar seumur hidup Tidak hanya melalui pendidikan formal, tetapi juga diluar sekolah. Contohnya, belajar melalui membaca, menulis, observasi, dan mendengar. Mempunyai pengalaman yang baik maupun yang buruk sebagai sumber belajar. 2. Berorientasi pada pelayanan Seorang pemimpin tidak dilayani tetapi melayani, sebab prinsip pemimpin dengan prinsip melayani berdasarkan karir sebagai tujuan utama. Dalam memberi pelayanan, pemimpin seharusnya lebih berprinsip pada pelayanan yang baik.3. Membawa energi yang positif Setiap orang mempunyai energi dan semangat. Menggunakan energi yang positif didasarkan pada keikhlasan dan keinginan mendukung kesuksesan orang lain. Untuk itu dibutuhkan energi positif untuk membangun hubungan baik. Seorang pemimpin harus dapat dan mau bekerja untuk jangka waktu yang lama dan kondisi tidak ditentukan. Oleh karena itu, seorang pemimpin harus dapat menunjukkan energi yang positif, seperti ; Percaya pada orang lain Seorang pemimpin mempercayai orang lain termasuk staf bawahannya, sehingga mereka mempunyai motivasi dan mempertahankan pekerjaan yang baik. Oleh karena itu, kepercayaan harus diikuti dengan kepedulian. Keseimbangan dalam kehidupan Seorang pemimpin harus dapat menyeimbangkan tugasnya. Berorientasi kepada prinsip kemanusiaan dan keseimbangan diri antara kerja dan olah raga, istirahat dan rekreasi. Keseimbangan juga berarti seimbang antara kehidupan dunia dan akherat. Melihat kehidupan sebagai tantangan, Kata 'tantangan' sering di interpretasikan negatif. Dalam hal ini tantangan berarti kemampuan untuk menikmati hidup dan segala konsekuensinya. Sebab kehidupan adalah suatu tantangan yang dibutuhkan, mempunyai rasa aman yang datang dari dalam diri sendiri. Rasa aman tergantung pada inisiatif, ketrampilan, kreatifitas, kemauan, keberanian, dinamisasi dan kebebasan. Sinergi, Orang yang berprinsip senantiasa hidup dalam sinergi dan satu katalis perubahan. Mereka 
selalu mengatasi kelemahannya sendiri dan lainnya. Sinergi adalah kerja kelompok dan memberi keuntungan kedua belah pihak. Menurut The New Brolier Webster International Dictionary, Sinergi adalah satu kerja kelompok, yang mana memberi hasil lebih efektif dari pada bekerja secara perorangan. Seorang pemimpin harus dapat bersinergis dengan setiap orang atasan, staf, teman sekerja. Latihan mengembangkan diri sendiriSeorang pemimpin harus dapat memperbaharui diri sendiri untuk mencapai keberhasilan yang tinggi. Jadi dia tidak hanya berorientasi pada proses. Proses daalam mengembangkan diri terdiri dari beberapa komponen yang berhubungan dengan: (1) pemahaman materi; (2) memperluas materi melalui belajar dan pengalaman; (3) mengajar materi kepada orang lain; (4) mengaplikasikan prinsip-prinsip; (5) memonitoring hasil; (6) merefleksikan kepada hasil; (7) menambahkan pengetahuan baru yang diperlukan materi; (8) pemahaman baru; dan (9) kembali menjadi diri sendiri lagi.

Sementara itu Yukl (2010: 2010mendefinisikan kepemimpinan sebagai "a traits, behaviors influence, interaction patterns, role relationship, and occupation of anadministrative position.'Dari pendapat Yukl menjelaskan bahwa kepemimpinan merupakan suatu sifat, perilaku pribadi, pengaruh terhadap orang lain, pola-pola interaksi, hubungan kerjasama antar peran, kedudukan dari suatu jabatan administratif, dan sebagai kemampuan menggerakkan, memberikan motivasi, dan mempengaruhi orangorang agar bersedia melakukan tindakan-tindakan yang terarah pada pencapaian tujuan melalui keberanian mengambil keputusan tentang kegiatan yang harus dilakukan.

Berdasarkan penjelasan di atas, dapa disimpulkan bahwa kepemimpinan yang pada dasarnya mengandung kesamaan asumsi yang bersifat umum seperti: (1) di dalam satu fenomena kelompok melibatkan interaksi antara dua orang atau lebih, (2) didalam melibatkan proses mempengaruhi, dimana pengaruh yang sengaja (intentional influence) digunakan oleh pemimpin terhadap bawahan. Disamping kesamaan asumsi yang umum, di dalam definisi tersebut juga memiliki perbedaan yang bersifat umum pula seperti: (1) siapa yang mempergunakan pengaruh, (2) tujuan daripada usaha untuk mempengaruhi, dan (3) cara pengaruh itu digunakan.

Jadi jelas bahwa unsur kunci kepemimpinan adalah pengaruh yang dimiliki seseorang dan pada gilirannya akibat pengaruh itu bagi orang yang hendak dipengaruhi. Peranan penting dalam kepemimpinan adalah upaya seseorang yang memainkan peran sebagai pemimpin guna mempengaruhi orang lain dalam organisasi/lembaga tertentu untuk mencapai tujuan. Pengetahuan dan keterampilan ini dapat diperoleh dari pengalaman belajar secara teori ataupun dari pengalamannya dalam praktek selama menjadi pemimpin. Namun secara tidak disadari seorang pemimpin dalam memperlakukan kepemimpinannya menurut caranya sendiri, dan cara-cara yang digunakan itu merupakan pencerminan dari sifat-sifat dasar kepemimpinannya.

\section{F. Kerangka Berpikir}

Dalam penelitian ini yang menjadi dasar penggalian nilai-nilai kepemimpinan yaitu karakteristik kepemimpinan dengan visi, misi dan strateginya. Kemudian digali lebih dalam melalui visi misi, kinerja dan kompetensinya.Kompetensi seorang pemimpin secara makro ada 3 yaitu :

1. Core Competence ( Kompetensi inti), bahwaq seorang pemimpin memang haus memiliki jiwa kepemimpinan.

2. Hard Competence (Kompetensi yang terkait dengan Pendidikan, Ketrampilan, dan sebagainya)

3. Soft Competence (Kompetensi yang terkait dengan nilai-nilai luhur, seperti rendah hati, jiwa besar, dan sebagainya)

Faktor tersebut tidak saja melekat dalam diri pemimpin pada waktu kini, namun juga harus dikembangkan sebagaimana yang diharapkan agar memenuhi fungsi dan tanggungjawabnya sebagai indikator kinerjanya menuju kompetensi seorang pemimpin 
hingga dicapai satu tatanan nilai-nilai kepemimpinan yang dapat dijadikan dasar pengembangan sumber daya manusia para guru maupun karyawan di sekolah tersebut. Kerangka berpikir dalam penelitian ini dapat dilihat dari gambar/bagan di bawah ini:

VISI, MISI \& STRATEGI
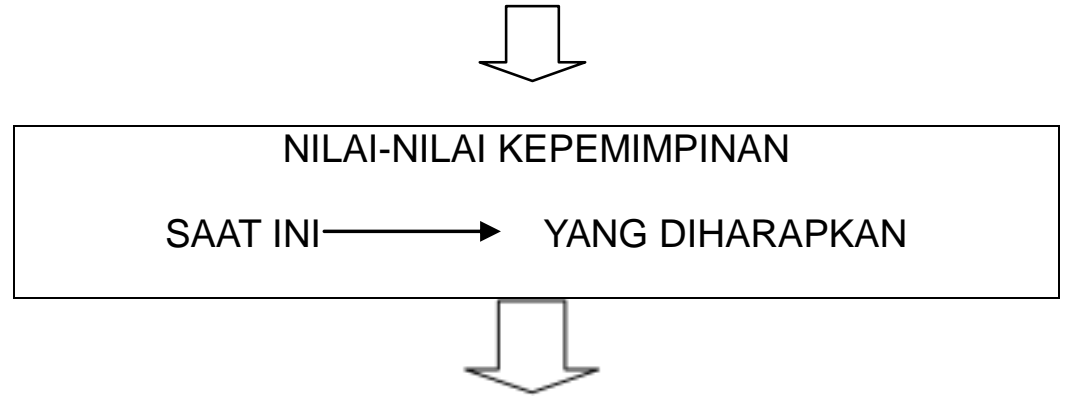

FUNGSI DAN TANGGUNGJAWAB UTAMA<smiles>C1CC2CCC1C2</smiles>

INDIKATOR KINERJA<smiles>C1C[C@H]2CC[C@H]1C2</smiles>

IDENTIFIKASI KOMPETENSI

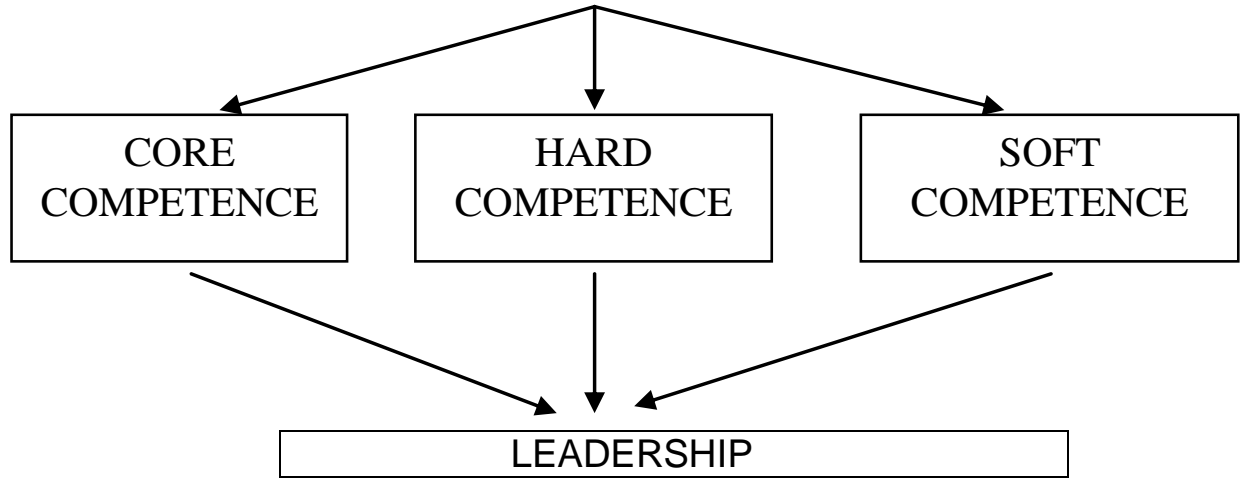

Gambar 1. Kerangka Berpikir

\section{G. Metodologi Penelitian}

1) Tempat dan waktu Penelitian

Penelitian ini dilakukan dengan penelaahan secara mendalam terhadap kepemimpinan di SMA ISLAM CIKAL HARAPAN 1 BSD dari Februari sampai dengan April 2018 dengan rincian penjadualan sebagai berikut :

\begin{tabular}{|l|l|l|l|l|}
\hline No. & MATERI & Februari & Maret & April \\
\hline 1 & $\begin{array}{l}\text { Perencanaan } \\
\text { masalah penelitian }\end{array}$ & 2 minggu & & \\
\hline 2 & $\begin{array}{l}\text { Penelusuran teori dan } \\
\text { daftar pustaka }\end{array}$ & & 2 minggu & \\
\hline 3 & $\begin{array}{l}\text { Penyusunan konsep } \\
\text { daftar pertanyaan }\end{array}$ & & 1 minggu & \\
\hline 4 & $\begin{array}{l}\text { Proses wawancara } \\
\text { dan penyusunan hasil } \\
\text { penelitian }\end{array}$ & & 4 Minggu \\
\hline
\end{tabular}

Tabel 2. Jadwal Penelitian 
Dalam pelaksanaan penelitian ini terdapat banyak kendala dan hambatan terutama terkait dengan keterbatasan berbagai hal dari peneliti itu sendiri, kesibukan narasumber sebagai kepala sekolah dimana kami melakukan penelitian. Oleh karena itu penjadwalan yang kami laksanakan untuk melakukan wawancara dan penggalian data lainpun cukup tersendat.

Masalah kepemimpinan adalah masalah yang sangat erat hubungannya dengan kehidupan sosial yang mempunyai kompleksitas permasalahan yang cukup tinggi, holistik, komprehensif dan dinamis. Alasan itulah mengapa penelitian ini menggunakan metodologi kualitatif.

Hal lain dalam penelitian ini sehingga menggunakan penelitian kualitatif adalah karena adanya keluwesan yang tinggi dalam mendapatkan informasi dari tangan pertama ( first hand informan), yaitu kepala sekolah SMA Islam Cikal Harapan 1 BSD.

Selain hal tersebut di atas, penelitian ini juga menggunakan Metode Focus Group Discussion sebagai salah satu bentuk penelitian kualitatif, yang merupakan wawancara kelompok yang ditekankan pada interaksi atas topik yang disodorkan. Menurut Umi Rusilowati ( 2013) ada lima karakteristik dalam FGD ( Fokus Grup Diskusi) yang peneliti lakukan dalam penelitian ini, sebagai berikut :

a. Jumlah peserta Focus Group Discussion sebaiknya empat sampai dengan dua belas orang

b. Peserta mempunyai karakteristik yang homogen

c. Informasi yang diambil dalam diskusi bukan bersifat konsensus atau rekomendasi untuk mengambil keputusan

d. Data yang dihasilkan adalah data kualitatif yang dapat memberikan gambaran dan pemahaman atas sikap, persepsi dan perasaan peserta.

e. Pertanyaan diajukan dengan cara yang mudah dimengerti oleh peserta, spontan, logis, dengan menekankan pemahaman atau proses berpikir dari peserta atas topik yang didiskusian.

\section{2) Desain Penelitian}

Dalam desain penelitian ini peneliti memiliki pedoman atau arahan dalam melakukan pengumpulan data, menganalisa, dan menginterpretasikan atau menerjemahkan data yang dikumpulkan untuk selanjutnya dibuat kesimpulan.

Penelitian ini akan didahului dengan proposisi studi tentang kepemimpinan, kemudian dilakukan analisa secara mendalam terhadap berbagai data yang telah terkumpul, sehingga didapat temuan-temuan.

a. Proposisi Studi

Untuk mendapatkan informasi-informasi yang relevan dengan penelitian ini, maka diperlukan arahan dan identifikasi agar informasi yang dibutuhkan tidak bias. Study proposisi dalam penelitian ini adalah :

1) Sebuah Kepemimpinan dimaknai dalam ruang lingkup Manajemen Sumber Daya Mausia

2) Pengembangan Kepemimpinan dilaksanakan dengan melakukan implementasi nilai-nilai

3) Tantangan kepemimpinan dalam menghadapi berbagai persoalan yang bersifat global

b. Unit Analisis

Yin dalam Rusilowati ( 2013 ) mendefinisikan bahwa unit of analysis is related to the way the initial research questions have been defined. Dalam penelitian ini unit analisisnya adalah SMA Islam Cikal Harapan 1 BSD dan pemimpinnya.

c. Keterkaitan data untuk Proposisi

Tabel 3. di bawah ini menunjukkan data yang relevan dengan studi proposisi serta 
penjelasan yang memadai

\begin{tabular}{|c|c|c|c|}
\hline No & Proposisi & Data Yang elevan & Keterangan \\
\hline 1 & $\begin{array}{lr}\text { Sebuah } & \text { Kepemimpinan } \\
\text { dimaknai dalam ruang lingkup } \\
\text { Manajemen Sumber Daya } \\
\text { Mausia }\end{array}$ & $\begin{array}{l}\text { Pemimpin dan } \\
\text { Kepemimpinan di } \\
\text { SMA ISLAM CIKAL } \\
\text { HARAPAN 1 BSD }\end{array}$ & $\begin{array}{lr}\text { Untuk menciptakan } \\
\text { kepemimpinan yang baik } \\
\text { sangat penting } \\
\text { melandaskan pada nilai- } \\
\text { nillai }\end{array}$ \\
\hline 2 & $\begin{array}{l}\text { Pengembangan } \\
\text { Kepemimpinan dilaksanakan } \\
\text { dengan } \\
\text { implementasi nilai-nilai kerja }\end{array}$ & $\begin{array}{l}\text { Visi, Misi dan } \\
\text { Strategi Pemimpin } \\
\text { dalam } \\
\text { mengembangankan } \\
\text { kepemimpinan di } \\
\text { level guru dan } \\
\text { karyawan }\end{array}$ & $\begin{array}{l}\text { Untuk sampai kepada } \\
\text { pencapaian } \\
\text { sekolah perlu adanan } \\
\text { arahan yang jelas dari } \\
\text { pemimpinnya }\end{array}$ \\
\hline 3 & $\begin{array}{l}\text { Tantangan kepemimpinan } \\
\text { dalam menghadapi berbagai } \\
\text { persoalan yang bersifat global }\end{array}$ & $\begin{array}{l}\text { Globalisasi dan } \\
\text { tuntutan } \\
\text { perkembangan } \\
\text { zaman serta } \\
\text { kompleksitas } \\
\text { masalah }\end{array}$ & $\begin{array}{l}\text { Kepemimpinan yang baik } \\
\text { harus } \quad \text { memiliki } \\
\text { kompetensi yang holistik }\end{array}$ \\
\hline
\end{tabular}

Tabel 3. Keterkaitan data untuk Proposisi

d. Kriteria Interpretasi Temuan-Temuan

Kriteria interpretasi temuan data dalam penelitian ini dirumuskan sebagai berikut :

1) Data diperoleh dari berbagai sumber yang relevan dan bukan asumsi dari peneliti

2) Data yang ada diinterpretasikan secara komprehensif dan obyektif

3) Metode dalam menginterpretasikan informasi harus benar

4) Data diinterpretasikan sesuai dengan fokus masalah

5) Data diperoleh langsung dari the first hand

\section{3) KRITERIA UJI KUALITAS DESAIN PENELITIAN}

Umi Rusilowati (2013) mengatakan bahwa sebuah penelitian ilmiah dituntut untuk memenuhi dua kriteria yaitu : logis dan empiris, dengan kata lain dituntut untuk berkualitas. Oleh karena itu, untuk memenuhi kedua kriteria tersebut dilakukan suatu pengujian dalam pembuktianya, termasuk dalam penelitian studi kasus.

Pada penelitian ini akan dipaparkan pengujian validitas data, keabsahan data atau kredibilitas data. Yaitu dengan pengamatan, peningkatan ketekunan, diskusi dan kajian serta analisa terhadap kasus kepemimpinan.

a. Validitas Kontruk

Untuk membuktikan kualitas sebuah penelitian perlu diuji dengan validitas kontruk, yaitu dengan :

1) Menggunakan multi sumber bukti

2) Membangun chain of evidence

3) Peninjauan kembali draf laporan case study yang bersangkutan dengan key informan.

b. Validitas Internal

Dalam penelitian ini setidaknya dilakukan penyusunan eksplanasi, yaitu sebuah penjelasann mengenai data-data atau informasi yang relevan digunakan dalam penelitian.

c. Validitas Eksternal

Dalam penelitian ini dilakukan analytical generalization terhadap kasus yang sedang diteliti, yaitu penggeneralisasian dalam proposisi teoritis yang bersifat kualitatif bukan sebuah populasi yang bersifat kuantitatif.

d. Reliabilitas 
Dalam penelitian ini dilakukkan keakuratan data sehingga bila pada waktu mendatang diadakan penelitian lagi dengan obyek yang sama akan mendapatkan hasil yang sama sehingga meminimalkan error dalam sebuah penelitian.

\section{4) JENIS DAN SUMBER DATA}

Dalam penelitian, pengumpulan data sangat penting dan harus diperhatikan dengan baik, terutama data yang relevan terhadap penelitian. Lebih lanjut menurut Umi ( 2013) terdapat enam macam sumber bukti yang bisa digunakan dalam penelitian studi kasius, yaitu : dokumen, rekaman arsip, wawancara, pengamatan langsung, observasi partisipan dan perangkat -perangkat fisik

Data-data yang digunakan dalam penelitian ini adalah dari referensi buku, majalah, weeb site, wawancara, grup diskusi dan sebagainya.

\section{Analisis Data}

Dalam melakukan analisis terhadap berbagai data yang masuk, peneliti menggunakan Chain of Evidence, yaitu melakukan analisis secara mendalam dan komprehensif mengenai obyek penelitian, dimulai dengan memaparkan identifikasi nilai kepemimpinan yang dilanjutkan dengan pengamatan secara cermat, sehingga ditemukan kesenjangan nilai. Dan tentu saja dengan ditemukannya kesenjangan nilai akan dilakukan upaya-upaya perubahan nilai-nilai kepemimpinan dengan munculnya nilai-nilai baru. Untuk mempermudah pemahaman tersebut dibuatkan skema 3.3. sebagai berikut MODEL ANALISA SITUASI DAN KONDISI

\section{Model Identifikasi Nilai}

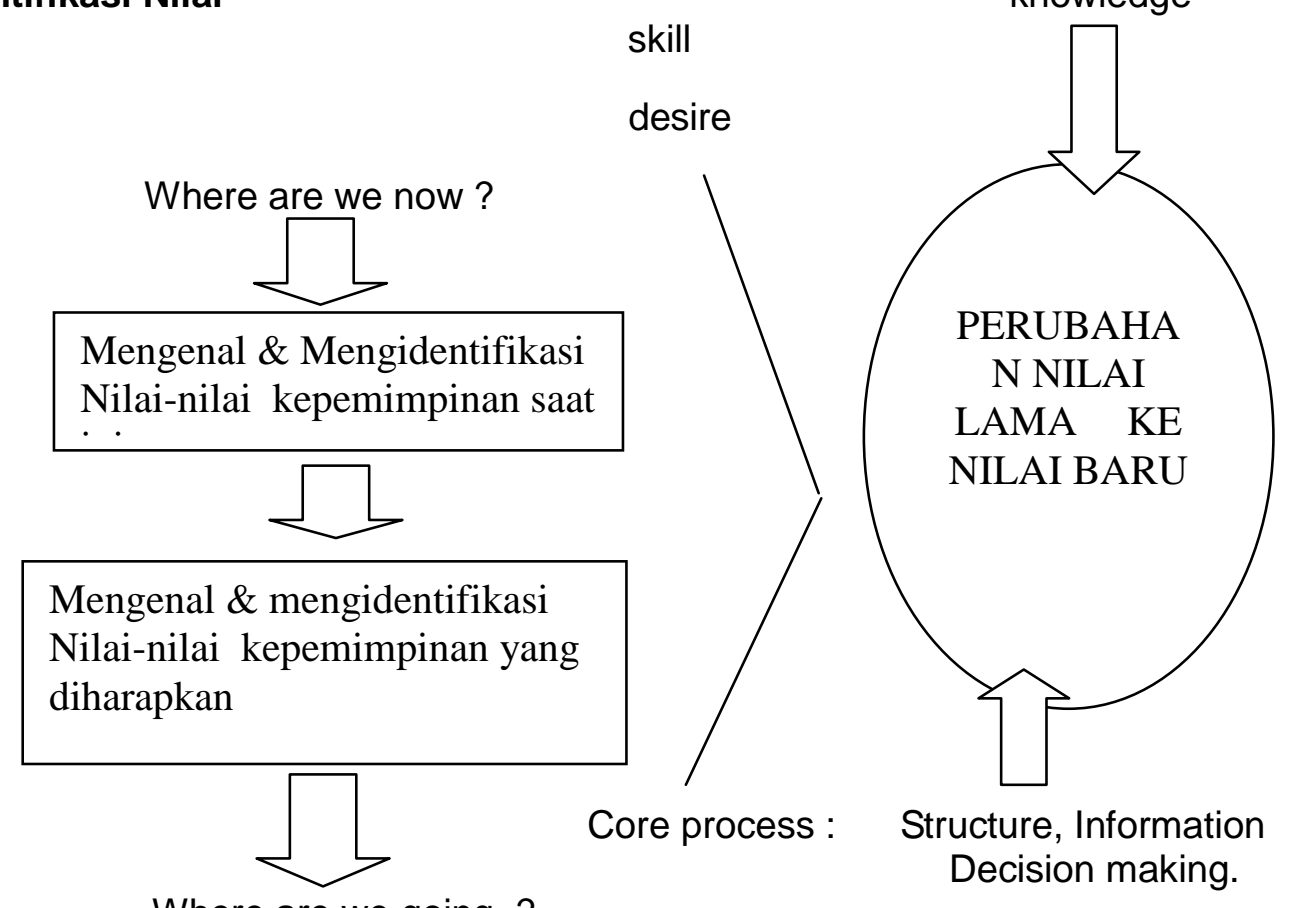

Where are we going ?

\section{Gambar 3.3.}

Model Identifikasi Nilai Kepemimpinan

Penjelasan dari skema yang peneliti buat adalah sebagai berikut :

Dalam pengidentifikasian nilai-nilai kepemimpinan, seorang pemimpin dituntut untuk mengenal dan mengidentifikasi nilai-nilai yang berlaku saat ini. Kemudian diteruskan dengan mengenal dan mengidentifiikasi nilai-nilai yang diharapkan.

Mendasarkan pada pengetahuan ( knowledge) dan ketrampilan (skill) serta 
semangat (desire), pemimpin mengubah dan membentuk habit melalui core process, pembuatan struktur, informasi yang jelas, keputusan yang tepat dan orang-orang yang baik yang berada dalam tim.

\section{Model Analisa Kesenjangan Nilai}

Dalam bagan di bawah ini seorang pemimpin harus mampu memperpendek jarak atau kesenjangan nilai-nilai yang berlaku di dataran guru dan karyawan dengan filosofi Manajemen atau kebijakan yang dibuat oleh manajemen. Kemudian melakukan perbaikan dan perubahan dengan memperhatikan kebijjakan perusahaan (Mindseting) serta dengan menaksir sulitnya merubah budaya organisasi ( Resistensi). Dan dengan melakukan sinergi keduanya, sehingga makin dekatnya kesenjangan yang ada, maka diharapkan dapat menciptakan hasil berupa budaya perusahaan yang dapat dijalankan.

\section{Model Perubahan Nilai Lama dan Pembentukan Nilai Baru}

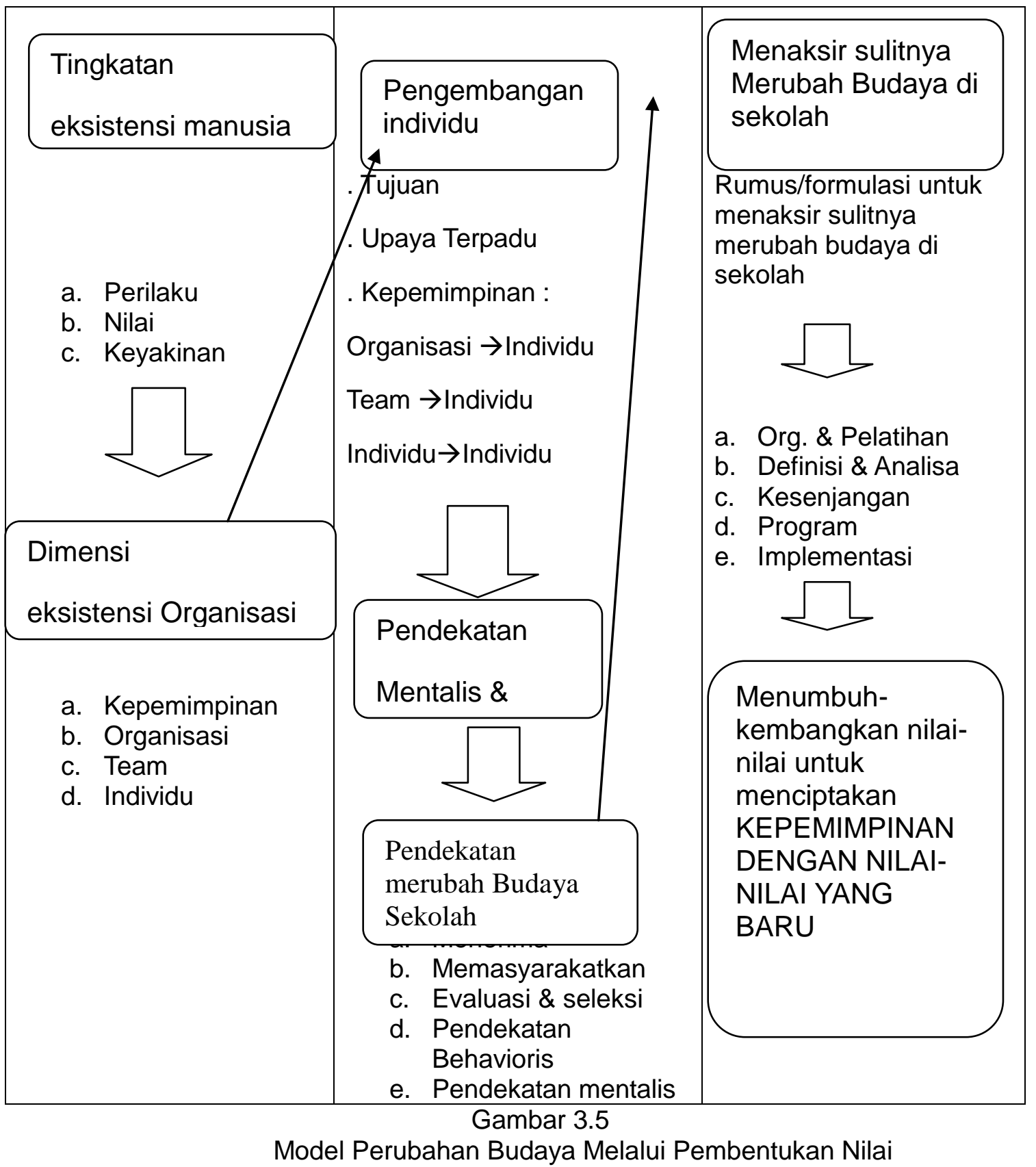


Model yang kedua ini dapat dijelaskan sebagai berikut:

Eksistensi manusia senantiasa ada dalam relasi, maka pentingnya setiap orang berorganisasi. Dan dalam berorganbisasi tersebut seseorang dapat tumbuh dan berkembang. Pertumbuhan dan perkembangan manusia itu senantiasa ada dalam kerangka budaya. Dan saat munculnya kesenjangan antara budaya perusahaan dan budaya pekerja, maka dibutuhkan berbagai pendekatan untuk mengembangkan budaya perusahaan, sehingga berdaya guna bagi perusahaan atau manajemen menuju terciptanya kepemimpinan yang baik.

Ketiga model analisa tersebut sangat penting dipaparkan mengingat dinamika masyarakat yang terus bergerak yang menimbulkan dampak yang saling berkaitan terhadap berbagai aspek kehidupan.

\section{H. Hasil dan Pembahasan Penelitian}

FOKUS GRUP DISKUSI :

Dalam melaksanakan kegiatan Diskusi terhadap beberapa koresponden, kami lakukan secara terpisah. Hal ini dimaksudkan agar mendapat jawaban yang beragam secara obyektif sehingga dapat dianalisa secara lebih komprehensif. Koresponden yang peneliti ambil sebanyak 5 orang, yaitu 3 orang guru dengan beragam masa kerjanya dan 2 orang siswa yang memiliki karakter yang homogen. Hal ini mendasarkan pada teori penelitian dengan metode kualitatif yang dipaparkan oleh Umi Rusilowati ( 2013) :

"Ada lima karakteristik dalam FGD ( Fokus Grup Diskusi) yang peneliti lakukan dalam penelitian ini, sebagai berikut :

1. Jumlah peserta Focus Group Discussion sebaiknya empat sampai dengan dua belas orang

2. Peserta mempunyai karakteristik yang homogen

3. Informasi yang diambil dalam diskusi bukan bersifat konsensus atau rekomendasi untuk mengambil keputusan

4. Data yang dihasilkan adalah data kualitatif yang dapat memberikan gambaran dan pemahaman atas sikap, persepsi dan perasaan peserta.

5. Pertanyaan diajukan dengan cara yang mudah dimengerti oleh peserta, spontan, logis, dengan menekankan pemahaman atau proses berpikir dari peserta atas topik yang didiskusian.

\section{1) Analisis Temuan Peneliti}

Berbagai temuan dalam penelitian, baik yang didapat dari observasi, wawancara maupun fokus diskusi penulis kritisi. Hal ini untuk menegaskan bahwa penelitian ini bukan hanya kualitatif sifatnya, namun juga memberi bobot serta nilai tambah sebagai masukan kepada SMA Islam Cikal Harapan 1 BSD.

Dalam visi misi yang dicanangkan sekolah dapat digarisbawahi bahwa "Strategi kepemimpinan yang digunakan dalam membangun sekolah adalah dengan membangun sumberdaya manusia seluruh guru, yaitu dengan menumbuhkembangkan nilai-nilai kepemimpinan."Keterkaitan nilai-nilai luhur dalam bekerja sangatlah penting karena bukan saja akan mengarahkan semangat bekerja, namun akan tetap terus berkembangnya etos kerja.

Dalam pandangan peneliti terjadi pengembangan nilai-nilai kepemimpinan yang dilakukan, yaitu "Strategi kepemimpinnan yang digunakan dalam membangun sekolah mengedepankan kekeluargaan, artinya budaya kekeluargaan sangat dikedepankan. namun membangun kepemimpinan itu tidak cukup hanya berbasis budaya ( sifat-sifat kekeluargaan) saja, namun juga harus mempertimbangkan struktur dan proses dalam pengembangannya, terutama dalam transformasi nilai-nilai guna pembentukan kepemimpinan baru atau yang di bawahnya. 
Kerangka berpikir yang peneliti lakukan dalam penelitian tentang kepemimpinan di SMA Islam Cikal Harapan 1 BSD dimulai dari Visi, Misi dan Struktur kepemimpinan yang jalankan. Kemudian dengan dukungan nilai-nilai saat ini diarahkan menuju terbangunnya nilai-nilai baru sesuai yang diharapkan. Hal tersebut dapat diketahui dari fungsi dan tanggungjawab utama seorang pemimpin dalam hal ini adalah kepala sekolah untuk mengarahkan sekolah termasuk guru-guru di dalamnya agar mampu berkembang. Indikator utama dari sebuah kepemimpinan dapat dilihat dari core competence nya, Hard competence nya dan soft competence nya, karena hal inilah yang akan mengarahkan kompetensi seorang pemimpin dengan basis nilai-nilai.

Peneliti merasa perlu mengkritisi konsep berpikir peneliti itu sendiri. Hal ini dilakukan untuk mengetahui sejauhmana kerangka konseptual yang dibuat berlaku atau tidak dalam penelitian ini. Hal ini harus dilakukan mengingat adanya temuan-temuan dalam penelitian.

Dan peneliti melihat bahwa kerangka konseptual yang dibuat cukup relevan dan berlaku untuk mengkaji masalah kepemimpinan dengan basis nilai-nilai. Hanya saja perlu pengembangan dalam kerangka tersebut, karena sebuah kepemimpinan itu tdak hanya menyangkut struktur saja, namun juga menyangkut proses dan budaya, terutama dalam hal kinerjanya. Dan skema yang dikembangkan secara holistik dan komprehensif menjadi gambar 6.1. sebagai berikut

Visi, misi dan strategi<smiles>C1CC2CCC1C2</smiles>

Dukungan nilai saat ini $\rightarrow$ yang diharapkan

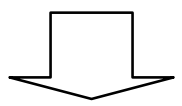

Fungsi dan Tangggungjawab<smiles>C1CC2CCC1C2</smiles>

Indikator kinerja
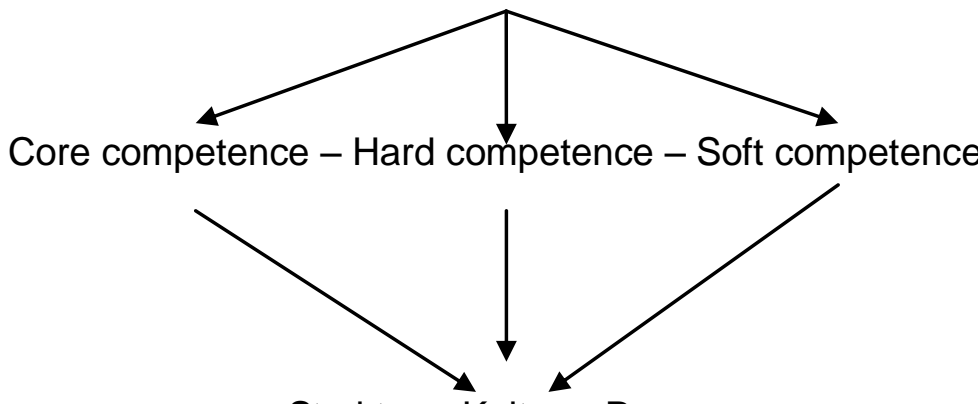

Struktur - Kultur - Proses

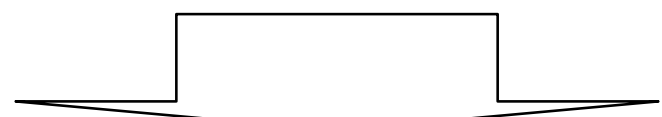

The Holistic Competence of Leader

Gambar 6.1. Pengembangan Kerangka berpikir 


\section{2) Perspektif Peneliti}

Terkait dengan temuan-temuan dalam penelitian tentang kepemimpinan di SMA Islam Cikal harapan 1 BSD, Peneliti membuat perspektif dari 3 sisi :

Pertama $\rightarrow$ Dari perspektif coverage area

Secara mikro, kepemimpinan berbasis kekeluargaan (budaya) dapat memberi nilai lebih kepada Kepala Sekolah itu sendiri dan guru-guru.

Secara makro, kepemimpinan berbasis nilai-nilai budaya tersebut dapat memberi nilai tambah kepada institusi sekolah, yaitu SMA Islam Cikal harapan 1 BSD.

Secara Nasional, kepemimpinan berbasis nilai-nilai (budaya) dapat memberi nilai tambah kepada negara.

Secara Regional, kepemimpinan berbasis nilai-nilai ( budaya) dapat memberi nilai tambah antar negara di tingkat asia.

Secara Global, kepemimpinan berbasis nilai-nilai ( budaya ) dapat memberi nilai tambah di dunia internasional.

Kedua $\rightarrow$ Dari perspektif waktu ( Time Frame )

Kepemimpinan dari perspektif waktu atau time frame, ada tiga masa, yaitu masa lalu terkait dengan old values, masa sekarang terkait dengan realitas dan masa depan sebagai new vision Kepemimpinan pada masa lalu, misalnya jaman kerajaan seperti Majapahit dan Sriwijaya, bisa bertahan selamanya tergantung dari seberapa besar kepemimpinan itu bisa dilembagakan dan dijadikan sebagai tolok ukur kinerja.

Oleh karena itu ke depan, dalam jangka pendek, kepemimpinan berbasis budaya dapat menjadi pertahanan budaya atau culture deffence. Dan untuk jangka menengah, kepemimpinan berbasis budaya ini dapat dijadikan sebagai pengembangan atau perluasan kepemimpinan agar lebih mengglobal. Serta jangka panjang, kepemimpinan berbasis budaya ini dapat dijadikan untuk memenangi persaingan global.

Ketiga $\rightarrow$ Dari perspektif spiritual. (Spiritual Vertical)

Kepemimpinan berbasis budaya dalam arti spiritual, dapat dijadikan sebagai :

a. Titik penemuan jati diri

b. Garis yang mem bidang untuk membentengi pengaruh dari luar

c. Sebagai sesuatu yang dapat lebih mendekatkan diri kepada Tuhan Yang Maha Esa, yaitu sebuah upaya menuju rahmatan lil 'alamin.

\section{3) Tantangan Kepemimpinan}

Dalam dataran dinamika kehidupan, globalisasi telah meruntuhkan tembok-tembok penyekat antar bangsa dan negara. Hal ini berarti pertautan antar negara semakin kuat dan tiada batas, oleh karena itu penguatan disetiap sektor kehidupan harus terjadi. Dan tak terkecuali masalah kepemimpinan.

Masalah global bidang pendidikani adalah adanya pergerakan (perubahan) karakter dan budaya manusianya. Terlebih dengan mulai banyaknya lembaga-lembaga atau institusi pendidikan yang memberi implikasi pada :

a. Tuntutan masyarakat yang makin complicated

b. Peraturan terkait masalah pendidikan yang makin ketat

c. Regulasi pemerintah yang makin ketat

d. Para pesaing ( sekolah-sekolah internasional) dari luar negeri yang makin banyak

e. Customer demand yang makin kuat

f. Pendidikan yang makin berkembang

g. Tuntutan pelayanan para guru yang makin prima

h. Tuntutan solution oriented

Hal-hal tersebut di atas menjadi tantangan yang tidak mudah untuk dihadapi bagi kepemimpinan di SMA Islam Cikal harapan 1 BSD. Terlebih kepemimpinan pada dataran guru yang memiliki tugas tidak ringan. Dan akan lebih sulit lagi bila pemimpin yang ada 
hanya memahami kultur atau nilai dan norma yang telah menetap lama yang telah dijalankan tanpa melihat nilai-nilai baru di era global ini..

\section{3..Mengatasi tantangan kepemimpinan}

Tantangan yang dihadapi oleh pemimpin ( kepala sekolah dan para guru) pada SMA Islam Cikal Harapan 1 BSD sangatlah berat, maka perlunya strategi bagaimana memenangi persaingan global. Untuk itu seorang pemimpin dituntut untuk mengembangan hal-hal sebagai berikut :

a) Human Capital Invesment ( $\mathrm{HCl}$ ), yaitu investasi di bidang pengembangan SDM kepada seluruh guru dan karyawan sekolah. Hal ini sangat penting mengingat persaingan dunia pendidikanpun begitu berat. Para pesaing dunia pendidikan bukan hanya pekerja lokal, namun juga pekerja asing yang tinggal di Indonesia. Begitu pentingnya pengembangan SDM bagi sebuah institusi pendidikan, maka sering didengar sebuah pernyataan mengenai pentingnya pekerja ( guru ) sebagai aset, "put people first in the global economy" Serta untuk mensejajarkan diri kepada tenaga kerja asing.

b) Information Technology ( IT ) Enhancement System, yaitu penyempurnaan di bidang teknologi agar memudahkan kerja, terutama dalam mengajar.

c) Networking ( Expansive Enlargement), yaitu perluasan kemitraan maupun kerjasama dengan berbagai pihak, baik yang sifatnya nasional, regional maupun internasional. Sehingga sekolah tidak berkutat bangga dengan prestasi yang ada saja.

d) Cultural Deffence ( Ketahanan Budaya), yaitu tetap menumbuhkembangkan nilai-nilai keluhuran bangsa dengan terus mengekplorasi budaya kearifan lokal. "Local Content with a global capacity". Guru-guru boleh dari internal wilayah lokal, namun kapasitas harus global.

e) Visionary Leadership, yaitu Seorang pemimpin dituntut bukan hanya mampu beradaptasi dengan perubahan zaman, namun harus turut menentukan arah perubahan itu sendiri. Seorang pemimpin tertuntut bukan hanya mampu bertahan dalam dinamika perubahan, namun mampu menumbuhkembangkan sekolah ( sustainable growth).

\section{Kesimpulan}

Setiap institusi/lembaga pendidikan harus melakukan perubahan untuk mengantisipasi kondisi yang terus berkembang. Begitu pulalah SMA Islam cikal harapan 1 BSD juga harus melakukan penyesuaian-penyesuaian, terutama terkait SDM nya khusunya lagi masalah kepemimpinan. Melakukan perubahan dan inovasi guna menghadapi tantangan dan persaingan global. Drucker mengatakan bahwa "Organisasi adalah tentang manusia. Oleh sebab itu tujuannya haruslah mengusahakan agar kekuatan manusia lebih efektif dan kelemahan-kelemahannya menjadi tidak relevan" (Drucker, 1977). Mendasarkan pada uraian tersebut maka kepemimpinan di SMA Islam Cikal harapan 1 BSD dipaksa untuk memiliki keunggulan kompetitif, artinya seluruh komponen SDM sekolah tersebut (Kepala sekolah, Guru dan karyawan)) harus memberdayakan dirinya sehingga mampu berkontribusi yang tinggi bagi organisasi sekaligus memenangkan persaingan dengan cara memberikan kepuasan kepada masyarakat (customer satisfaction). Ini berarti kepuasan masyarakat ( para orangtua siswa) harus menjadi titik tolak dalam kemajuannya.

\section{J. Saran}

Untuk meningkatkan kualitasan SDM sekolah, maka direkomendasikan kepada SMA ISLAM CIKAL HARAPAN 1 BSD, hal-hal sebagai berikut :

1. Perluasan Networking ( Kerjasama dengan Sekolah-sekolah, lembaga pendidikan atau sejenisnya). 
2. Penetrasi Market lebih luas (Penjaringan siswa baru)

3. Pengembangan pelayanan Pendidikan

4. Integrasi ke depan (Adaptasi perkembangan/dinamika masalah pendidikan)

5. Integrasi ke belakang (Maintain guru-guru dan karyawan)

6. Integrasi vertikal/horizontal (Kerjasama antar pimpinan yayasan, kepala sekolah dan guru-guru serta antar karyawan sekolah)

7. Diversifikasi konsentrik ( Fokus pada peningkatan kinerja kepala sekolah dan guru serta karyawan sekolah dengan meminimalkan komplain dan keluhan )

\section{K. Daftar Pustaka}

Al-Quran dan Terjemah, Asy Syifa , Semarang, 1998.

Anwar, Saifudin, Reliabilitas dan Validitas, Pustaka Pelajar, Yogyakarta, 2003

Cresell, John W., Research Design : Qualitatif, Quantitative and Mixed Methods Approaches. Edisi ke-2. India : sage, 2003

Henry Simamora, Manajemen Sumber Daya Manusia, STIE YKPN, Yogyakarta, 2001

Ivancevich.2008. Organization Behavior. Penertbit: MGGraw-Hill education. New York.

Kartono, Kartini, Pemimpin dan Kepemimpinan. Edisi Kedua, Cetakan Kesembilan, Raja Grafindo Persada, Jakarta, 2001

Lepine, Colquiit.2009. Organization Behavior. Penertbit: MGGraw-Hill education.New York

Notoatmodjo, Spekidjo, Pengembangan Sumber Daya Manusia, Cetakan ketiga, Rineke Cipta, Jakarta, 2003

Rusmin, Tumanggor, dkk, Ilmu Sosial \& Budaya Dasar, Cetakan ke-2, Kencana Prenada Media Grup, Jakarta, 2012

Sugiyono, Metode Penelitian Kuntitatif Kualitatif dan R\&D, Cetakan ke-13, Alfabeta Bandung, 2011

Wahjosumidjo, kepemimpinan dan Motivasi, Ghalia Indonesia, Jakarta, 2000

Umi, Rusilowati, Manajemen Pengetahuan, Asmoro Mediatama, Tangsel, 2013

Teguh Yuwono, Pengembangan Kepemimpinan Berbasis Budaya Sebuah Tantangan Kepemimpinan Baru - Studi Kasus di Divisi Internasional BNI 46 Jakarta, Tesis, Universitas Pamulang, Tangerang Selatan, 2014.

http://www.gudangmateri.com/2010/08/model-kepemimpinan-masa-lalu-dan-kini.html http://erdiyansyah.wordpress.com/2010/08/14/kepemimpinan-transformasional-dankepemimpinan-transaksional-pengaruhnya-terhadap-kepuasan-kerja-pegawai/

http://www.hendryrisjawan.com/index.php?option=com_content\&view=article\&id=84:kepe mimpinan-yang-melayani\&catid $=52$ :others-article \& Itemid $=69$

.(http://yakobtomatala.com/2010/04/15/sejarah-ilmu-kepemimpinan/comment-page-1/ 